\title{
Genetic Divergence Analysis in Khedha Bhaji (Amaranrhus dubius Mart.) Genotypes for Yield and its Component Characters
}

\author{
Arti Kujur* and Vivek Kumar Kurrey
}

Department of Vegetable Science, Indira Gandhi Krishi Vishwavidyalaya, Raipur - 492012 Chhattisgarh, India

*Corresponding author

\author{
A B S T R A C T
}

\section{Keywords}

Khedha, Amaranrhus dubius Mart., Diversity genetic,

Divergence, $\mathrm{D}^{2}$ analysis, Cluster analysis.

\section{Article Info}

Accepted:

17 October 2017

Available Online:

10 December 2017
An investigation was carried out to identify the extent of genetic divergence that exist for the yield and yield contributing characters of 25 genotypes of Khedha Bhaji (Amaranthus dubius Mart.) using Mahalanobis $\mathrm{D}^{2}$ analysis. Analysis of variance showed significant difference among the genotypes for most of the characters studied. The genotypes under study fell into 5 clusters. The distribution pattern indicated that the distribution pattern indicated that the maximum number of genotypes (7) was included in cluster (I) and (V) followed by cluster IV (6) and cluster II (4), and the minimum number was in cluster III (1). The intra-cluster distance varied from 0.000 to 3.157 . The maximum intra cluster distance was shown by cluster I (3.157) followed by cluster IV (2.482), cluster II (2.390), cluster V (1.871) and cluster III (0.000), which indicate distance within the cluster. The characters like test weight of seed contributes highest (42.95\%) to divergence followed by leaf length $(17.11 \%)$, dry matter per cent $(13.42 \%)$, plant height $(12.75 \%)$, fibre content per cent (2.68), petiole length (1.34), number of leaf per plant (1\%), root length (1\%), yield $\mathrm{kg}$ per plot $(1 \%)$ days to $50 \%$ flowering and duration $(0.33 \%)$ contributed maximum towards genetic diversity. Hence these characters could be given due importance for selection of genotypes for further crop improvement programme.

\section{Introduction}

Khedha (Amaranthus dubius Mart.) is one of the most popular leafy vegetable also known as Khedha bhaji and jari bhaji in Chhattisgarh belongs to the family Amranthaceae. It is a rich and inexpensive source of carotenoid, protein, vitamins and dietary fibre (Prakash and Pal, 1991; Shukla et al., 2003). Amaranth uses the $\mathrm{C} 4$ cycle photosynthetic pathway. It has a high rate of photosynthesis and excellent water use efficiency at high temperatures and high radiation intensity. Chhattisgarh state has very rich in leafy vegetable Amaranthus genotypes for various traits like plant habit, branching habit, stem pigmentation, leaf venation, seed colour, petiole colour, leaf characters, viz., shape, size, etc. (Kurrey et al., 2015a). Leafy vegetables play a major role in nutritional requirement of the tribal and local population in remote parts of the Chhattisgarh. Leafy vegetable not only provide food quantity but also make significant contribution to the population nutrition throughout the year (Chauhan et al., 2014). Traditionally, genetic diversity studies are based on differences in morphological characters and qualitative 
traits. It has been used as a powerful tool in the classification of cultivars and also to study taxonomic status (Kurrey et al., 2015b). Traditionally, genetic diversity studies are based on differences in morphological characters and qualitative traits. It has been used as a powerful tool in the classification of cultivars and also to study taxonomic status. Morphological traits continue to be the first step in the studies of genetic relationships in most of the breeding programmes (Van Bueningen et al., 1997). The $\mathrm{D}^{2}$ analysis proposed by Mahalanobis (1936) has been reported to be an effective tool to assess the genetic divergence among the types. The $\mathrm{D}^{2}$ analysis has been established by several investigators like Shobha and Dharmatti (2004) in vegetable mesta, Rana et al., (2005) in grain amaranthus, Anuja and Mohideen (2007) in vegetable amaranthus for measuring the degree of divergence and for ascertaining the relative contribution of different characters to the total divergence. In the present investigation, therefore, the genotypes were subjected to $\mathrm{D}^{2}$ analysis to find out nature and extent of genetic diversity present in 25 genotypes of Khedha (Amaranthus dubius Mart.) for genetic improvement.

\section{Materials and Methods}

The experimental material for the study comprised of 25 genotypes collected from Chhattisgarh and laid in randomized complete block design (RBCD) with three replications at the Horticultural Instructional and Research Farm, Department of Horticulture, Indira Gandhi Krishi Vishwavidyalaya, Raipur (C.G.) lies between $21^{\circ} 16^{\prime} \mathrm{N}$ latitude and $81^{\circ} 36^{\prime}$ E longitude with an altitude of 289.56 meters above the mean sea level. The experiment was conducted during Rabi season 2014-15. The soil properties like organic carbon (\%) 0.60, Available $\mathrm{N}\left(\mathrm{kg} \mathrm{ha}{ }^{-1}\right)$ 275.00, Available $\mathrm{P}\left(\mathrm{kg} \mathrm{ha}{ }^{-1}\right) 16.75$ and Available K $\left(\mathrm{kg} \mathrm{ha}^{-1}\right) 303.00$ Soil Reaction
pH 7.09 and Electrical conductivity (n mh $\mathrm{cm}^{-}$ $\left.{ }^{1}\right) 0.19$ was observed in the site of experiment. The seeds were sown in $20 \mathrm{~cm}$ apart between rows and $15 \mathrm{~cm}$ within the row. Standard agronomic practices and plant protection measures were taken as per schedule. Test weight was recorded before sowing of crop. Observations were recorded on five randomly selected plants per replication plant height $(\mathrm{cm})$, number of leaf per plant, leaf length $(\mathrm{cm})$, leaf width $(\mathrm{cm})$, petiole length $(\mathrm{cm})$, number of branches per plant, dry matter \%, root length $(\mathrm{cm})$, days of $50 \%$ flowering, fibre content $\%$, test weight of seed $(\mathrm{g})$, yield (q/ha)., were recorded at 60 days after sowing while days to $50 \%$ flowering, duration of crop were recorded periodically. The analysis of variance was carried out for all the characters and then data was analyzed following multivariate analysis of Mahalanobis (1936) and genotypes were grouped into different clusters following Tocher's method (Rao, 1952).

\section{Results and Discussion}

The genetic divergence existing in twenty five Khedha (Amaranrhus dubius Mart.) genotypes was studied by employing $\mathrm{D}^{2}$ analysis for 13 quantitative characters. On the basis of $\mathrm{D}^{2}$ analysis, twenty five genotypes were grouped into five clusters (Table 1). Maximum number of genotypes were grouped into cluster I (IGKB-1, IGKB-2, IGKB-4, IGKB-8, IGKB-10, IGKB-12, IGKB-24) and cluster V (IGKB-6, IGKB-11, IGKB-13, IGKB-14, IGKB-15, IGKB-17, IGKB-18) included seven genotypes in each cluster whereas, cluster IV (IGKB-5, IGKB-7, IGKB-16，IGKB-19，IGKB-20，IGKB-22) included six genotypes, which is followed by cluster II (IGKB-9, IGKB-21, IGKB-23, IGKB-25) included four genotypes and cluster III (IGKB-3) included only one genotype. The intra-cluster distance varied from 0.000 to 3.157 . The maximum intra 
cluster distance was shown by cluster I (3.157) followed by cluster IV (2.482), cluster II (2.390), cluster V (1.871) and cluster III (0.000), which indicate distance within the cluster (Table 2). These results are in general agreement with the findings of Venkatesh et al., (2014) in vegetable amaranthus and Kurrey et al., (2015b) in chench. An examination of average intra and inter cluster distance indicated that genotypes within cluster had little divergence from each other with respect to aggregate of effects of 13 characters understudy. Therefore, the chance of obtaining recombinants in segregating generations by crossing the members of same cluster is very low. It is therefore, suggested that crosses should be attempted between the genotypes belonging to cluster separated by large inter cluster distances. To realize much variability and high heterotic effect, recommended that parents should be selected from two clusters having wider inter cluster distance (Thomas and Lal, 2012). Raman and
Singh (1987) suggested that genotypes belonging to clusters separated by high genetic distance maybe used in hybridization program to obtain a wide spectrum of variation among the segregates and in the present study similar suggestion had been made. that maximum inter cluster distance was observed between cluster IV and III (5.909) followed by cluster III and II (5.677), cluster V and III (5.611), cluster III and I (5.276), cluster IV and I (4.769), cluster II and I (4.709), cluster V and I (4.169), cluster $\mathrm{V}$ and IV (2.951). The minimum inter-cluster $\mathrm{D}^{2}$ values were recorded in case of cluster $\mathrm{V}$ to cluster II (2.890) followed by cluster IV and II (2.810). The higher inter-cluster distance indicated greater genetic divergence between the genotypes of those clusters, while lower inter-cluster values between the clusters suggested that the genotypes of the clusters were not much genetically diverse from each other.

Table.1 Composition of clusters

\begin{tabular}{lll}
\hline $\begin{array}{l}\text { Cluster } \\
\text { Number }\end{array}$ & $\begin{array}{l}\text { Number of genotypes } \\
\text { included }\end{array}$ & Name of genotypes \\
\hline I & 7 & IGKB-1, IGKB-2, IGKB-4, IGKB-8, IGKB-10, IGKB- \\
& & 12, IGKB-24 \\
II & 4 & IGKB-9, IGKB--21, IGKB-23,IGKB-25 \\
III & 1 & IGKB-3 \\
IV & 6 & IGKB-5, IGKB-7, IGKB-16, IGKB-19, IGKB-20, IGKB- \\
& 7 & 22 \\
V & & IGKB-6, IGKB-11, IGKB-13, IGKB-14, IGKB15, \\
\end{tabular}

Table.2 Intra (bold) and Inter cluster distance values in khedha

\begin{tabular}{llllll}
\hline \hline Cluster Number & I & II & III & IV & V \\
\hline I & $\mathbf{3 . 1 5 7}$ & & & & \\
II & 4.709 & $\mathbf{2 . 3 9 0}$ & & & \\
III & 5.276 & 5.677 & $\mathbf{0 . 0 0 0}$ & & \\
IV & 4.769 & 2.810 & 5.909 & $\mathbf{2 . 4 8 2}$ & \\
V & 4.196 & 2.890 & 5.611 & 2.951 & $\mathbf{1 . 8 7 1}$ \\
\hline \hline
\end{tabular}


Int.J.Curr.Microbiol.App.Sci (2017) 6(12): 2248-2253

Table.3 Mean performance of genotypes in individual cluster for yield and its components

\begin{tabular}{|c|c|c|c|c|c|c|c|c|c|c|c|c|c|c|}
\hline \multicolumn{2}{|c|}{$\begin{array}{l}\text { Character } \\
\text { Cluster }\end{array}$} & $\begin{array}{l}\text { Plant } \\
\text { height }\end{array}$ & $\begin{array}{l}\text { No. of } \\
\text { leaf } \\
\text { /plant }\end{array}$ & $\begin{array}{l}\text { Leaf } \\
\text { length }\end{array}$ & $\begin{array}{l}\text { Leaf } \\
\text { width }\end{array}$ & $\begin{array}{l}\text { Petiole } \\
\text { length }\end{array}$ & $\begin{array}{l}\text { No. of } \\
\text { branches } \\
\text { /plant }\end{array}$ & $\begin{array}{l}\text { Root } \\
\text { length }\end{array}$ & $\begin{array}{l}\text { Test } \\
\text { weight } \\
\text { of seed }\end{array}$ & $\begin{array}{l}\text { Dry } \\
\text { matter } \\
\%\end{array}$ & $\begin{array}{l}\text { Days } \\
\text { to } 50 \% \\
\text { flower } \\
\text { ing }\end{array}$ & $\begin{array}{l}\text { Fibre } \\
\text { content } \\
\%\end{array}$ & Duration & $\begin{array}{l}\text { Yield } \\
\mathrm{kg} / \mathrm{plot}\end{array}$ \\
\hline I & 7 & 22.28 & 28.54 & 3.75 & 2.57 & 2.80 & 4.57 & 10.44 & 0.80 & 23.41 & 49.14 & 10.15 & 32.76 & 1.83 \\
\hline II & 4 & 34.31 & 31.55 & 6.69 & 4.46 & 3.97 & 5.28 & 14.59 & 1.23 & 20.86 & 61.50 & 11.43 & 34.92 & 2.62 \\
\hline III & 1 & 21.55 & 36.80 & 4.98 & 3.74 & 3.34 & 10.82 & 9.86 & 0.72 & 21.61 & 61.67 & 10.75 & 33.33 & 1.30 \\
\hline IV & 6 & 42.71 & 45.42 & 6.04 & 3.91 & 3.39 & 5.30 & 14.11 & 0.98 & 18.49 & 57.22 & 10.63 & 31.44 & 3.04 \\
\hline V & 4 & 28.52 & 31.95 & 6.83 & 4.14 & 4.02 & 5.05 & 14.35 & 0.90 & 16.83 & 55.52 & 9.99 & 28.10 & 2.36 \\
\hline
\end{tabular}

Table.4 Contribution of each character to divergence

\begin{tabular}{|c|c|c|c|c|c|c|c|c|c|c|c|c|c|c|}
\hline Characters & $\begin{array}{l}\text { Plant } \\
\text { height } \\
(\mathrm{cm})\end{array}$ & $\begin{array}{l}\text { No. } \\
\text { of } \\
\text { leaf } \\
\text { per } \\
\text { plant }\end{array}$ & $\begin{array}{l}\text { Leaf } \\
\text { length } \\
(\mathrm{cm})\end{array}$ & $\begin{array}{l}\text { Leaf } \\
\text { width } \\
(\mathrm{cm})\end{array}$ & $\begin{array}{l}\text { Petiole } \\
\text { length } \\
(\mathrm{cm})\end{array}$ & $\begin{array}{l}\text { No. } \\
\text { of } \\
\text { branches } \\
\text { per plant }\end{array}$ & $\begin{array}{l}\text { Root } \\
\text { length } \\
(\mathrm{cm})\end{array}$ & $\begin{array}{l}\text { Test } \\
\text { weight } \\
\text { of seed } \\
(\mathrm{gm})\end{array}$ & $\begin{array}{l}\text { Dry } \\
\text { matter } \\
\%\end{array}$ & $\begin{array}{l}\text { Date } \\
\text { of } \\
50 \% \\
\text { flower } \\
\text { ing }\end{array}$ & $\begin{array}{l}\text { Yield } \\
\text { kg/plot }\end{array}$ & $\begin{array}{l}\text { Fiber } \\
\text { content } \\
\%\end{array}$ & duration & total \\
\hline $\begin{array}{l}\text { Number } \\
\text { times } \\
\text { appearing } \\
\text { first time }\end{array}$ & 38 & 3 & 51 & 0 & 4 & 18 & 3 & 128 & 40 & 1 & 3 & 8 & 1 & 298 \\
\hline $\begin{array}{l}\text { Per cent } \\
\text { contribution }\end{array}$ & 12.75 & 1.00 & 17.11 & 0 & 1.34 & 6.04 & 1.00 & 42.95 & 13.42 & 0.33 & 1.00 & 2.68 & 0.33 & 100 \\
\hline
\end{tabular}


The cluster mean values showed a wide range of variations for all the characters undertaken in the study (Table 3). The cluster mean for various traits showed that different cluster respond differentially for various traits. Cluster IV expressed highest mean value for plant height and number of leaf per plant and yield kg per plot. Cluster III showed highest mean value for number of branches per plant and days to $50 \%$ flowering. Cluster II showed highest mean value for test weight of seed, root length, fibre content, and duration. Cluster V showed highest mean value for petiole length. Cluster I showed highest mean value for dry matter per cent (Table 3).

In the contribution of each character to divergence presented in table 4 showed test weight of seed contributes highest $(42.95 \%)$ to divergence followed by leaf length $(17.11 \%)$, dry matter per cent $(13.42 \%)$, plant height (12.75\%), fibre content per cent (2.68), petiole length (1.34), number of leaf per plant $(1 \%)$, root length $(1 \%)$, yield kg per plot $(1 \%)$ days to $50 \%$ flowering and duration $(0.33 \%)$. The results of the present study was close agreement with findings of Pandey and Singh (2011), who reported that leaf size, grain yield/plant, harvest index, length of top lateral branches/plant were contributed more than other characters on most of the total genetic divergence (Table 4). The results of the present study were close agreement with findings Ahammed et al., (2013) in amaranthus and Kumari and Singh (2015) in finger millet.

The inter-cluster distances in present investigation were higher than the intra cluster distance reflecting the wider diversity among the breeding lines of the distant group. Hence, it is suggested that intercrossing of genotypes from diverse clusters showing high mean performance will be helpful in obtaining better recombinants with higher genetic variability, This implied that there was no parallelism between genetic divergence and geographical divergence. This has been observed that diverse the parents within its overall limits of fitness, the greater are the chances of heterotic expression in F1's and broad spectrum of variability in segregating generations. In this study, group constellation showed that cluster I (IGKB-1, IGKB-2, IGKB-4, IGKB-8, IGKB-10, IGKB12 , IGKB-24) were highly divergent from all other genotypes and may be used as parents in transgenic breeding programme and may directly be used as a pure line variety for leaf yield and it is component characters in khedha (Amaranthus dubius Mart.)

\section{References}

Ahammed, A. U., Rahman, M. M. and Mian, M. A. K. 2013. Multivariate analysis in stem amaranth (Amaranthus tricolor). Bangladesh J. Pl. Breed and Genet. 26(1): 1117.

Chauhan, D., Shrivastava, A.K. and Patra, S. (2014). Diversity of leafy vegetables used by tribal peoples of Chhattisgarh, India. Int. J. Curr. Microbiol. App. Sci, 3(4): 611-622.

Kumari, S. and Singh, S. A. 2015. Assesment of genetic diversity in promising finger millet (Eleusine coracana L. Gaertn.) genotypes. The Bioscan. 10(2): 825830.

Kurrey, V.K., Sharma P.K., Dixit A. (2015a). Evaluation of Chench (Corchorus acutanguls Lam.) Genotypes for Various Horticultural Traits. Trends in Biosciences. 8(22): 6088-6091.

Kurrey, V.K., Sharma P.K., Dixit A. and Ramteke, V. (2015b). Estimation of genetic divergence among chench (Corchorus acutangulus Lam.) Genotypes. The Ecoscan, Special issue, 8: 319-323:

Mahalanobis, P. C. 1936. On the generalized distance in statistics. Proc. Nat. Inst. 
Sci., India, 21: 49-55.

Pandey, R.M., and Singh, R. 2011. Genetic divergence in grain amaranth (Amaranthus hypochondriacus L.). Genetika, 43(1): 41- 49.

Prakash, D. and Pal, M. (1991). Nutritional and anti-nutritional composition of vegetable and grain amaranth leaves. Journal of Science of Food and Agriculture, 57: 573-583.

Prakash, D. and Pal, M. (1991). Nutritional and anti-nutritional composition of vegetable and grain amaranth leaves. Journal of Science of Food and Agriculture, 57: 573-583.

Raman, M. V. and Singh, D. P. 1987. Genetic divergence in mungbean (Vigna radiata (L.) Wilczek). Genome. 30: 835-837.

Rao, C. R. 1952. Advance Statistical Methods in Biometrics Research. Hofaer Pub. Darion. pp. 371-378.

Shobha, S. and Dharmatti, P. R. 2004. Genetic Divergence in Vegetable Mesta. Karnataka J. Agri. Sci. 17(2):
275-278.

Shukla, S. and Singh, S.P. (2003). Correlation and path analysis in grain amaranth (Amaranthus spp.). Indian Journal of Genetics and Pant Breeding, 63(2): 163-174, 2003.

Shukla, S. and Singh, S.P. (2003). Correlation and path analysis in grain amaranth (Amaranthus spp.). Indian Journal of Genetics and Pant Breeding, 63(2): 163-174, 2003.

Thomas, N. and Lal, G. M. 2012. Genetic divergence in rice genotypes under irrigated conditions. Ann. Pl. Soil Res. 14(2): 109-112.

Van Beuningen, L. T., Busch, R. H. 1997. Genetic diversity among North American spring wheat cultivars, In: Analysis of the coefficient of parentage matrix. Crop Sci. 37: 564-573.

Venkatesh, L., Murty, N. and Nehru, S.D. 2014. Analysis of genetic diversity in grain amaranth (Amaranthus spp.). Indian J. Genet., 74(4): 522-525.

\section{How to cite this article:}

Arti Kujur and Vivek Kumar Kurrey. 2017. Genetic Divergence Analysis in Khedha Bhaji (Amaranrhus dubius Mart.) Genotypes for Yield and its Component Characters. Int.J.Curr.Microbiol.App.Sci. 6(12): 2248-2253.

doi: https://doi.org/10.20546/ijcmas.2017.612.260 